\title{
A Political and Economic History of Ethiopian Nuer from the 1890s - 1991
}

\author{
Shimels Ayele Yalew \\ Department of History and Heritage Management, Faculty of Social Science, Bahir Dar University, Bahir Dar, Ethiopia \\ Email address: \\ samuelshimels229@gmail.com

\section{To cite this article:} \\ Shimels Ayele Yalew. A Political and Economic History of Ethiopian Nuer from the 1890s - 1991. International Journal of European \\ Studies. Vol. 4, No. 1, 2020, pp. 27-36. doi: 10.11648/j.ijes.20200401.14
}

Received: March 12, 2020; Accepted: June 15, 2020; Published: August 4, 2020

\begin{abstract}
The Nuers are among the diverse ethnic groups of Ethiopia who live in its southwestern periphery. But there was limitation in recording historical experiences of the Nuers. Thus, this research attempts to record an economic and political history of Ethiopian Nuers. Methodologically, it tended to use narrative history. It has arranged chronologically and attempted to explain how and why events occurred. A qualitative interpretation and analysis of primary sources collected from interviews and archives were undertaken. In addition, critical cross checking of books, journals, reports, and other relevant documents supplemented primary sources. Accordingly, the Nuers had indigenous political tradition. They practiced egalitarian form of political structure. Economically, they were predominantly pastoralists. However, political and economic changes commenced after the arrival of Ethiopian state representatives to the region. Politically leaders with newly introduced political titles had emerged among the Nuers. Those political leaders served as intermediaries between the government and the people. An average degree of diversified economic activities also introduced. Human induced and natural factors eroded reliability of cattle herding. As a result, they began to cultivate crop in some areas of the Baro Salient. Besides, the 1974 Ethiopian revolution brought political reorganization. Some Nuer elites nominated as real government functionaries.
\end{abstract}

Keywords: Nuer, Politics, Economy, Egalitarian, Feudalism, Pastoralism, Changes

\section{Introduction}

The Nuers are among the Nilotic people of Eastern Africa. The majority of the Nuers live in Southern Sudan. Southern Sudanese Nuer lives around the junction of the Nile River with the Bahr el Ghazal and Sobat Rivers. Their settlement also extends up to the Sobat across the Ethiopian Baro salient [1]. Although they are not comparable with the Southern Sudanese, the Nuers who live in Ethiopia have a significant number. Nowadays, Ethiopian Nuer lives in Akobo, Jikow, Wanthow, Lare, and Itang special district. They also live in some urban areas of Gambella National Regional state. They address themselves as Naath meaning "people" and their language Thuok Naath meaning "language of the people" [2].

Although they live in peripheral areas, Ethiopian Nuers were not bare of political and economic changes of the country across different periods. The egalitarian form of political tradition was part of their history until the beginning of the $20^{\text {th }}$ century. Later feudal form of political structure replaced Egalitarian tradition. However, the feudal way of political arrangement was abandoned after 1974. Besides, in the earlier period, Nuers had engaged mainly in pastoralism. Then, their economy had started to be diversified [3].

\section{Background of the Region}

Socio-economic interaction between lowland Nilotic people of Gambella and highlanders was started before Imperial Ethiopia incorporated the region in the 1890s. Trade was the leading instrument of interaction that preluded state presence in the region. Imperial Ethiopia arrived in the region having diplomatic and economic interests. Diplomatically, it sought to out-compete British colonial covet of expansion to the western highlands of Ethiopia. Economically, it was engrossed to uphold the lucrative ivory and cattle trade of the late 19th and early 20th centuries [4]. Officially, Gambella incorporated to Ethiopia after long and complex negotiations between Emperor Menelik II and the British. In 1902, the boundary delimitation of Ethiopia and Anglo-Egyptian Sudan was made. After the adoption of the boundary agreement, 
Gambella became the westernmost border of Ethiopia. This placed the majority of Nuer inside Sudan and the overwhelming number of Anywak in the side of Ethiopia [5].

Before WWII, the Ethiopian government had moved steadily and flexibly towards the region. Scholars viewed presence of the Ethiopian government in the region differently; strong and weak. Nevertheless, before and after the Italian invasion of the region was conventionally known as part of the Ethiopian empire. In fact, Britain had influence over the region using the Enclave of Gambella as the pretext. After the independence of Sudan in 1954, the enclave was continued as part of the Ethiopian state. The Baro salient remain firmly on Ethiopian hands. During Imperial and early Derg Period Gambella had the status of an Awraja (Sub province) in the Illubabour Province [6].

During the Derg period, the attendance of the government on the region increased and established tighter than before. Attempts were made to address imbalances between the center and the periphery. Some practical measures were taken to enhance a sense of belongingness to the national identity. Expansion of social services, proscription of ethnic inequality, endorsement of literacy campaign, and representation of the locals in the regional administration were some actions taken by the Derg [7]. However, the Derg's effort of local empowerment and integration of the region was not convenient. Its absolute control over all aspects of life and unpopular socialist projects/agenda overshadowed the endeavor. The revolution tried to demolish indigenous cultural institutions. Some cultural practices suppressed as reactionary and backward elements.

Moreover, the Derg regime in the region was characterized by the presence of cross border political activities. The SPLM/A presence in the region had profound effect. In retaliation for Sudan's acceptance of Ethiopian rebels the Derg begun to assist Sudanese rebel groups. In the 1980s, Derg allowed SPLM/A to use Gambella as a base and military training center. Not only was the SPLM/A allowed cross into Ethiopian territory, but also recruited from the rural population in Gambella. As aresult, the Sudanese army began to launch frequent counter-insurgent operations against local Ethiopian civilians in Gambella. On the other hand, local grievance emerged that resulted in the establishment of rebel groups such as GPLM [8].

After the fall of the Derg and the endorsement of ethnic federalism, Gambella was promoted to a national regional state in the Federal Democratic Republic of Ethiopia (FDRE). It is located in the south-western Ethiopian Lowlands bordering Oromia Regional State from the north and east, SNNPRS in the south-east and the Republic of South Sudan from the west. Administratively the region is divided into three zones along with the three major ethnic groups [9]. The 1995 redistribution of zones, allocated three districts to the Nuer, and later rose to four. Those zones were further divided into twelve districts; five under Anywak zone, two under the Majang zone, four under the Nuer zone and one special district Itang. Itang is directly accountable to the regional state council. The Four districts of Nuer Zone are Akobo,
Jikow Lare and Wanthow [10].

\section{Statement of the Problem, Significance, and Methodology}

Ethiopia hosts peculiar ethnic, religious, economic, and cultural diversity. These diverse peoples deserve to be studied intensively on their own terms, as the bearer of enclosed economic activities and a unique political tradition. Besides, different institutions of any cultural and its contribution to the groups' adaptation has to be examined [11]. However, Ethiopian historiography faced shortcomings to address those issues. Imbalance of archaeological and literary sources, early contact with foreigners, and absence of written culture set off discrepancy. In earlier periods, its emphasis was northern half of the country. Recent experiences began to give attention for central and southern parts of the country overlooking peripheral regions. Historical studies of Ethiopia often tend to concentrate on events at or nearer to the center of political power [12].

Several literary documents produced about the Nuer people since the third decade of the $20^{\text {th }}$ century. Those literary works emanated from two disciplines; history and anthropology. The anthropological works of Evans E. Pritchard were widely known literatures about the Nuer. Accordingly, the Nuer: description of the mode of livelihood and political institution of a Nilotic people which was published in 1940, provided detail accounts. But Pritchard had studied only the Nuer who was under British administration [13]. In addition, Pritchard produced another book entitled Nuer religion in 1956. In this book, greater emphasis was given only to the traditional religion of the Nuer. Another anthropologist Sharon Elaine Hutchison wrote Violence, legitimacy, and prophecy: Nuer struggles with uncertainty in South Sudan and A guide to the Nuer of Jonglei state in recent times. But those works of Hutchinson were geographically limited to South Sudan. The Nuer who lives in Ethiopia wasn't included [14].

Historians also began to produce literary works about the Nuer in recent times. Recording history of the Nuer was made by Naol Stringham entitled, Marking Nuer Histories: Gender, Gerontocracy, and the Politics of Inclusion in the Upper Nile from 1400 - 1931 in 2016 . However, both the spatial and temporal scope of this research was limited to South Sudan and up to 1931 respectively [15].

But, on the top of geographical location, the eastern Nuer in Ethiopia and western Nuer in South Sudan had differences in social, economic and political experiences. This difference was sounder particularly after the delimitation of the international boundaries between Ethiopia and Sudan. For instance, one of the obvious differences between the two groups was exposure for changes. The easterners were more adaptive to change due to exposure and incorporation of large numbers of Dinka and Anuak. But the westerners were more traditionalists for geographical and historical reasons [16]. 
From the Ethiopian side, researches were conducted on the region by different scholars. Dereje Feyissa produced successive anthropological works about the Nuer and Anuak of Gambella. Interethnic interaction and alternative citizenship were the main themes raised in articles written by Dereje [17]. Temesgen Gebeyehu has also written articles about Nuer and Anywak of the region. Ethnic conflict, interaction, and cohabitation in Africa: the case of Nuer and Anywak in 2013, and Identity, centralization and resistance in Ethiopia: the case of Nuer and Anywak in 2014, were his works. But those articles focused on the inter-ethnic interaction and reaction to the central government from the peoples of Gambella region [18].

Nevertheless, this research primarily focused on the economic and political changes in the history of Ethiopian Nuer from the 1890 s -1991 . It attempted to reconstruct the change and continuities in the history of Ethiopian Nuer politically and economically. Thus, it focused to answer questions such as: why an egalitarian form of administration abandoned? What elements of Nuer economic activity changed? How the Nuer reacted to feudalism? And what are the effects of the 1974 Ethiopian revolution on the politics of Nuer? Its main aim was to reconstruct the political and economic traditions in the history of Nuer. Moreover, it emphasized on the different factors for economic and political changes.

This research would have several significances. It could provide a clue to fill the gap in the available literature. As stated before, most of the written documents about Ethiopian Nuer in particular and the Nuer in general, were anthropological, sociological, and other social science fields. There exist limitations in producing historical records concerning Ethiopian Nuers. Therefore, it comes with the new trend of recording their political and economic history. Besides, this research would inspire other researchers to engage in further studies on the Nuer. Again, it can provide important input for academicians, researchers, governmental and non-governmental organizations to understand the economic and political history of Ethiopian Nuer.

The author preferred qualitative design to undertake this study. This research design generated results of qualitative forms. Primary sources mainly from Ethiopian archives and library agency were exploited. In addition, information taken from interviewees also utilized for this study. Books and journal articles supplemented primary data sources. The author has taken into account of different methods of data collection and instruments. The first method was an in-depth and semi-structured interview. Interviewees were selected using non probability purposive sampling based on their understanding to the issue. Audio recording and writing notes were fundamental instruments. Notes have taken from government archives. The author also engaged in the critical and comprehensive reading of secondary sources. It is narrative history using interpreted sources. Interpreted sources are arranged not only to show what happened in the past but also answers why and how it happened.

\section{Early Nuer Settlement in Ethiopia}

The period after 1970s witnessed remarkable territorial expansion of the Nuer. As a result, Nuer expansion reached to southwestern part of Ethiopia in the second half of $19^{\text {th }}$ century. In the years before their expansion they were divided in to Jikany (Eastern), Bentiew (Western Jikany), Lou, and Pangak. Among those four subgroups of the Nuer, it was Eastern Jikany who arrived first along the Ethiopian frontier. The Gaajak, Gaajok, and Gagwang sections of Eastern Jikany began to set up a temporary settlement. Indeed, the Gaajak overwhelmed early settlement of Nuers in Ethiopia. Their settlement became operant in Gambella, particularly in Akobo and Jikow districts [19].

Several factors pulled the Nuer to the region. First, the resources available in the region attracted the Eastern Jikany Nuers. The region had rich natural resources, such as, large expanse of arable land, huge surface and groundwater resources, fish resources, and forest resources. These factors made the region best suited to pasture and crop production [20]. The first settlement inside the Ethiopian territory was not permanent. Environmental factors forced them to have seasonal settlements. The Nuers as semi-pastoralists, graze cattle on the plains of Akobo and Jikow in the dry season (about November to May), in Ethiopia. They also move to lands along the Sobat River in Southern Sudan during the rainy season (June to October). During the wet season, the Nuer together with cattle move to upland settlements away from flooding, while during the dry season they move to the shores of the rivers, where the moisture provides abundant pasture and cultivable land. The pools and swamps formed by flooding offer fish reserves to the Nuer [21].

Secondly, eastward expansion of the Nuer was dictated by inter-ethnic conflicts. The eastern Jikany Nuer groups particularly Gaajak, Gaajok, and Gagwang were forced by the Shilluk to abandon the Sobat River around the last quarter of $19^{\text {th }}$ century. Thus, they began to search an alternative place of pasture and settlement. The areas to the east of their contemporary settlement were suitable. Rivers with steady flow attracted Nuers. The areas alongside rivers were favorable for crop cultivation, grazing, and fishing particularly at the dry season [22].

Thirdly, the Nuer incursion and settlement had begun in a massive way earlier when the Anywak abandoned the lowest reaches of their land to escape Mahdi's raids [23]. In 1887 the Mahdist forces from Sennar raided Blue Nile downstream as far as Nasir. Those forces returned to the Blue Nile through Baro, raiding a section of the Nuer on the Pibore, and forcing the Anywak to flee the Baro. A vacuum was created with the evacuation of Anywak in fear of the Mahdi's force. The open space drew the attention of Eastern Jikany Nuer to graze there without contenders. The Nuer effectively used the opportunity occurred due to the retreat of Anywaks to occupy parts of the Baro salient. This marked the beginning of the major Nuer encroachment in to the settlement of Anywaks in Ethiopia [24].

The Nuers accessed those lands in different ways. They 
formed marriage alliance when they meet with major settlement by other ethnic groups.

At the first time the marriage relationship benefited both groups. For the Nuer, it is inexpensive to marry an Anuak whose bride wealth payment is lower; and for the Anuak, the marriage ensures the flow of cattle wealth. But these gradually come to serve as a heart for more immigrants and, due to this; the immigrants outnumbered the Anuak, who are then left with the two option of joining the Nuer kinship and political structures or leaving their villages to keep up their identity [25].

Assimilation through marriage enabled the Nuers to have access for extra land. And where the settlement was small, movement to these pastures was regulated by effective occupation among the various Nuer clans. The resourcedriven movements of the Nuer have resulted not only in territorial gain, but also demographic expansion. The expansion which was begun by population pressure further boosted their number [26].

The Nuer had developed different mechanisms of adopting and assimilating the people in newly conquered areas. They incorporated neighbors, though this was obviously not unique to their expansion into the Gambella region. As practical assimilationists the Nuers have absorbed many Anywak into their society. In some parts of mixed settlement areas processes of ethnic assimilation (Anywak becoming Nuer) was under way. In the long term, this helped them with the expansion of their cultural space as well [27].

\section{The Indigenous Political Tradition of the Nuer}

Before incorporation into Ethiopia and its immediate succeeding years, the Nuers were bare of institutionalized political leaders, such as chiefs or kings with intimidating authority. Indeed, the Nuer Social arrangement had contained many types of spiritual leaders and ritual experts. Khor Muon in charge of peacemaking, Khor Touch in charge of issues on water, Khor Tang in charge of war, and others were some of the spiritual leaders. The main responsibility of spiritual leaders was to advise on respective field of specialization [28]. Among the Nuer, there was no enacted law and political power with legislative or judicial functions. In other words, there was no individual with legal authority or a council of elders to hold court. Their political system lacks formal authorities to compel and bring social order [29].

However, disputes were settled by the use of an informal adjudicator known as the leopard-skin chief or Khor Muon. The leopard-skin chief was not a political authority but a mediator and the Man of Cattle. Similarly, other ritual agents had no political status or functions. But they were prominent and respected in their locality. Ritual leaders were specialists accepted due to their ritual capacity in the various departments of Nuer social life and nature. Besides, the main criteria to be ritual agents were individual personality such as, trustfulness, respect and love of the community, the number of cattle owned, and others [30].

The Nuers were an egalitarian society. Elected spiritual agents were without special privileges. Only if problems occurred the community used to visit spiritual agents to get advice. Those agents didn't expect any fear and special respect from the community. Unfortunately, if they need to be respected the community would not be voluntary to do so [31].

The Nuer political tradition resembles modern democratic principles. Every member of the community had an unrestricted right to participate in an assembly. They had the right to forward opinion and indicate solutions for every problem. But the first speakers were elders, youngsters would follow. They frequently promote and demote village chiefs. This tradition forced the village chiefs to undertake their social responsibility appropriately [32].

\section{Earlier Economic Activities}

The Nuers practiced mainly pastoral lifestyle which was the characteristic of cattle complex of the Nilotic societies. Pastoralism was the pillar or backbone of their economy. They led a wandering life in search of water and vegetation. The Nuer in group or section had pastures and water supplies. They had used to move seasonally in search of land for this livelihood strategy. Some sections of the Nuer were fortunate enough to have wet-season settlements situated not far from dry-season grazing lands. Other sections had to flock seasonally for distances of several kilometers in search of better grazing land [33].

The Nuers had strong social and economic attachment with cattle. People depended on cattle as insurance against manmade and natural hazards. Ethiopian Nuers struggled with both manmade and natural hazards. Frequent and seasonal flooding, drought, and anti-crop insects recurred in the area [34]. Interethnic and intra ethnic conflicts were some of the social calamities that occurred in the history of Ethiopian Nuers. They used herds as vital sources of milk, meat, leather, and dung. During disasters, when their crops destructed cattle were accessible sources of food [35].

Cattle were the fundamental medium through which Nuer created enduring social interaction among them and establish new alliances with outsiders. The economic and social value attached to cattle had influenced the relationships among the Nuer and neighbors. Social status in the Nuer community was determined by the number of cattle owned [36]. Transfers of bride wealth (cattle) alone ensured a man heir who would carry on his name and line. High access to cattle, moreover, could enable a man to increase social acceptance and participate in the negotiation of extended social alliances through its exchange. It was the payment of blood wealth (cattle) employed by the people to resolve violent conflicts peacefully. A serious crime committed by a member of the Nuer could be negotiated through cattle exchange. In short, cattle determined their interaction and activities. Cattle in the Nuer had indispensable social values beyond mere economic significance [37]. 
The Nuers were not economically bare of crop production. They had trend of growing crops consisting primarily sorghum and maize, complemented by small plots of tobacco, groundnuts, and other more minor crops. They engaged in the practice of crop production more than once within a year. Small plots of fast-maturing crops used to grow at the dry season in the foreshore of rivers. Comparatively narrow strips riverine lands in eastern Jikany Nuer along the upper Sobat and Baro Rivers were suitable for crop cultivation. The crops produced in the dry season shores enabled them to escape from hunger temporarily [38].

The next term of crop production among the Nuers was the summer season. Summer plots arranged farther from flooding sites. The crop produced in the summer season was larger than the dry season. In the summer season, the Nuers were capable of producing abundant crops in comparison with the dry season. But, it was not sufficient enough as a sustainable source of food. The traditional granary to store harvested crops was as a result, too small. Moreover, flooding and drought were the main obstacles against the crop grown by the Nuer. The prevalence of flooding and drought also forced the Nuers to shift their settlement [39]. Then, the people were known as pastoralists because of different seasonal settlements.

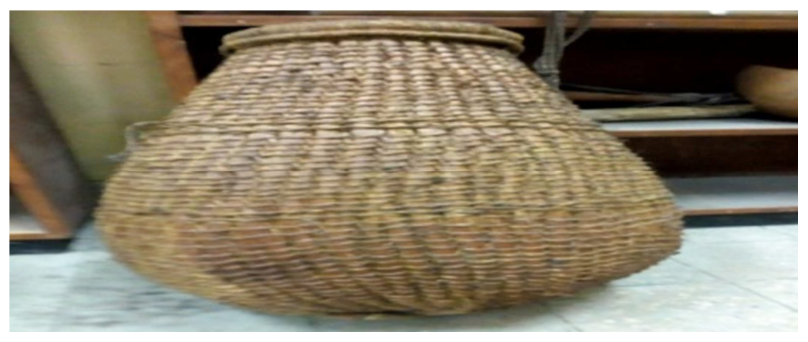

Figure 1. A traditional granary of the Nuer.

In addition, fishery supplemented the economy of Nuers. Their settlement along the rivers and the swamp region enabled to catch fishes as an alternative source of food. The Baro salient, which is networked with rivers and streams inside the Ethiopian territory, has an abundant fish resource. The Nuers who live around Baro, Gilow, Pibore, Akobo Rivers and other small streams used to extract the fish resources. These Rivers are very rich not only by the number of fish resources but also its variety [40]. Fishing could be conducted from the main water body or swamps after draining of flooding. Mostly the Nuer built temporary camps around the rivers in the dry season in search of water and vegetation. Similarly, fishing grounds were open and suitable in the same season. A wet-season village included collective rights in its immediate water sources, fishing pools, and grazing grounds. The rights of access to specific fishing pools were also controlled by specific Nuer sub-ethnic and/or clan groups. Access to fishing pools and tonic lands might be shared with non-group members, but it should be with the permission of sections or segments that arrived first in the area [41].

Furthermore, the Nuers used to hunt wild animals. The youth in a group often visit hunting grounds [42]. They need to hunt wild animals as a source of food and skin. Initially, they had been hunting using traditional material such as a spear. They chase wild animals and throw a spear. It was very tiresome and difficult to be successful easily using traditional materials. The introduction of modern firearms and involvement in the long-distance trade, however, made hunting easy for the Nuer. They have got those modern firearms from Turuk (civilized) people, who arrived in the area since the late $19^{\text {th }}$ century. The Nuer had taken cattle and ivory to get modern firearms in exchange [43].

\section{Commencement of Feudalism and Its Advancement}

After the incorporation of the region to imperial Ethiopia political rearrangement had continued. Despite the appointment of officials from the central government, local Nuer officials were grown to power bearing novel titles. They were able to assume these titles from ordinary Balabat up to Qegnazmach. This was made because centrally appointed regional and local authorities needed help from the indigenous leaders. Language, cultural barriers and restricted resources forced the central government to rely on the indigenous traditional leaders [44].

The Balabats were low ranked, placed below the governor or district administrator and acted as intermediaries between their society and the government. The main functions of Balabats were to maintain security, assist the regional and local governors in collecting taxes and tributes, and mobilize the local people when it was demanded by the government [45]. The Balabats were known as Khor in Nuer language. The main Balabats were known as Khor Midid and vice Balabats were called Khor Mithot. They adopted the term Khor from the Anywak when they came to have closer interaction. The Anywak had the native political tradition of accepting authority often called kings or Kaworo in their language [46].

The appointment of coercive officials was an odd adventure for the egalitarian Nuer. They resisted the imposition of alien tradition in particular and authoritative domination in general. The stiff resistance that faced Fitawurari Khoryom Tut by his fellow Gaajak Nuers was one manifestation of such reaction [47]. They took a relatively long time to adopt the authoritative political power of imperial Ethiopia. Of course, the protracted and flexible incorporation process had its drawbacks.

As part of the Ethiopianization of the Nuers, Majid had appointed Khoryom Tut, a Gaajak Nuer chief living at Kurthony on the north bank of the Baro, as a Fitaurari [48]. There was no other Ethiopian official ever made such a demand. Khoryom Tut traveled to Addis Ababa, where he was hosted and presented with a robe of honor and a shield and thereafter worked diligently to convince his fellow Nuer of the benefits of being Ethiopian subjects [49].

The Nuer reacted to the claim of Majid and the imposition 
of political authority in two ways. Some Nuer were distressed at the Ethiopian initiatives. They also tried to punish Khoryom Tut for accepting to be subjects of the emperor. Fellow Gaajak Nuer attempted to fight with Koryom and narrowly escaped with the help of the British. Others warmly welcomed the initiation brought by Majid. They liked to be under the light and nominal administration of the Ethiopians compared to the strict and virtuous rule of the British. They saw it as a direct challenge to the colonial government and in Ethiopia; they need no longer be concerned with British justice [50].

Representatives of the imperial government used to nominate local Balabats of the Nuer on the basis of acceptance among society. The main criterion of selection was being respected and popular on behalf of the community. They Khors were from Gathot or elect of the people. Active participation in social activities, being orator, having a large number of cattle and braveness would bring fame and popularity which was a precondition to be a Khor. Girazmach Ray Khun and Girazmach Thiang Jote of Lare, Qegnazmach Chuol Kid of Kuatgar, Qegnazmach pal Muon Check, Qegnazmach Pal Chay and Girazmach Tongyik Tenjah of Jikow were some of the khors among the Nuer who had served as loyal Balabats [51].

Qegnazmach Pal Chay assumed the title after the resignation of Qegnazmach pal Muon Chiek in 1956. Pal was removed from power and sent to prison in Gore as a punishment for his participation in the intra ethnic conflict among the Gaajak Nuer and after being accused of killing a man. Pal Chay's early descent and wise activities among the community helped him to assume the title Qegnazmach. Again and Girazmach Tongyik Tenjah came to power in the same process [52].

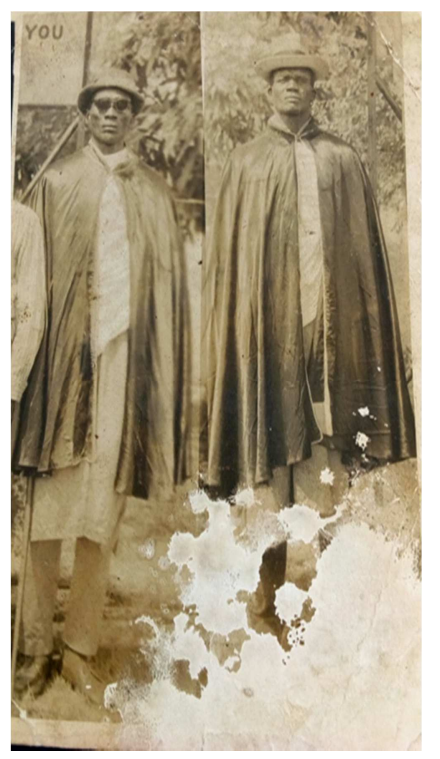

Figure 2. Qegnazmach Pal Chay (left) and Girazmach Tongyik Tenjah (Right).

There was incentive payment and a budget allocated for the Nuer Balabats. However, the budget was very limited in comparison with the number of Balabats. For instance, in 1957 , the allocated amount of many was only 240 birr but the numbers of Balabats (both Nuer and Anywak) were 235 excluding their Balabat police [53].

The Nuer Khors were allowed to have an official visit to Addis Ababa. The transport expenses were covered by the provincial and sub-provincial administration. Fitawurari Koryom Tut was the first in this regard. They had also attended the coronation anniversary of Emperor Haile Selassie. Some fifteen Nuer Khors and Anywak Kaworos, for instance, were traveled to attend the anniversary in 1958. The amount of money paid for transport expenses was 1229.90 Birr which was financed by the sub-provincial administration of Gambella [54]. This was made as part of the Ethiopianization process. Their official visit to the center of the imperial administration would allow them to meet with other feudal nobles. Communication with those nobles often enabled them to exchange ideas, ways of public administration and more on tax collection. It was also provided an impetus for the imperial government to work closely with the Balabats and won the loyalty of the people.

Nevertheless, the Balabats of Nuer had discontent with the imperial administration. Particularly they expressed resentment upon sub-provincial administration. The first cause of resentment was the amount of incentive money paid for them. The amount of money allocated to the subprovincial administration as an incentive for Balabats was too little. It was below one birr if it would be paid in every month for all. Hence, the administration was forced to pay for them once a year. Moreover, the budget allocation was not clear [55].

The second reason was all the incentives given by the Ethiopian government were not enough for them when they compare it with those in Sudan in the same position. In this regard, the application letter written in Amharic from Jikow Balabats send by the governor to the sub-provincial administrator can be good evidence as it has taken directly below.

... as we have applied frequently before, this district is located near the border; and the attention given as well as monthly salary paid for Balabats of the neighboring country made our Balabats jealous of it. As a result, they have frequently asked why they are working without payment as far as they become Balabats and participate in government works. Then in 1973 the main and vice Balabats were sent to Addis Ababa to meet with the Emperor and presented their demands [56].

Above all, the aforementioned limitations of the government and response, the Balabats had encountered weakness. They had failed to collect tribute or tax from the people. Indeed, the economic activity of the people, who were dominantly pastoralists with seasonal movement, made tax collection difficult. The other limitation of Balabats was their participation in intra-ethnic and inter-ethnic conflicts. The resignation and imprisonment of Qegnazmach pal Muon Chiek in 1956, was because of his participation in the intraethnic conflict among the Gaajak section of Nuer [57]. 


\section{Attraction to Farming and Its Challenges}

Ethiopian Nuers had greater affection for cattle. However, recurring famines, displacement, and permanent settlement noticeably around urban areas forced them to diversify livelihood. They started integrate cattle herding with stable farming, fishing in permanent villages on the Ethiopia side. After the establishment of permanent settlement, they began to visit market centers. Permanent access to and control over vital natural resources such as land and water gained more significance among them [58].

The Nuers had used backward agricultural methods and tools. They had been plowing using handmade local hoes. It was very difficult to cultivate on larger area. It was not allowed to use oxen for crop cultivation among the Nuer. Their culture strongly prohibits using oxen to plow land. The maximum size of farmland that could be cultivated was only two hectares. However, in comparison with the farming methods and materials, the amount used to collect was indispensable. This was resulted from the fertility of the land. The amount of cereal collected by the Nuer using a hoe and a small land in two seasons was comparable with highland Ethiopian farmers who used oxen and plow relatively larger plot. The Nuers undertook crop cultivation in two seasons. In the dry season, they settle around rivers and grow crops. Whereas when the lands around rivers become flooded they left it to relatively safer land and grow crop there again. For instance, the Nuers who had been in Jikow district shifted their settlement to Baro River every dry season. There they grew crops and involved in fishing. During the summer season, when the river became flooded they shift their settlement to Lare. Lare was relatively safer from floods due to its altitude and distance from the river. They also grew crops there in Lare during the wet season [59].

The crop grown through hoe plowing by the Nuer faced different natural hazards that resulted in the loss of crops. Among those natural hazards, flooding and drought were very distractive. In 1961 and 1962, flooding from Baro and Pibore Rivers brought heavy loss on the crops grown by the people of Jikow and Akobo districts. Two years later, the crop was grown in Itang, Jikow, Akobo, and Jor districts were dry due to a shortage of rain. In 1974, in the districts of Akobo, Itang, and Jikow anti crop worm was occurred and brought significant loss [60]. Besides, the Nuer also engaged in trading activities. But after the enclave was owned by Ethiopian government taxation started. The items which had greater demand among the Nuers began to be expensive. It also brought repercussion on participation in trade. The arrival of refugees enabled the Nuer to engage in trade with them. The refugees in the camps sold food items for the host community. In exchange, the Nuer used to visit the market to sell milk and tobacco [61].

\section{The 1974 Ethiopian Revolution and Its Impact}

After the 1974 revolution and change of regime, the Nuer experienced a different form of political structure. Reforms promulgated by the new government began to radiate every direction of the country. Though, it was slower than the regions at the center, peripheral areas also became the laboratory of socialist experiments. The districts in which the Nuers live in took part in different socialist reforms. The approaches used to administer the Nuer during the imperial period were changed. Efforts employed and attention given to the region had increased after the revolution than before. This was happened due to the political motive of the Derg [62].

Indeed, the initial impact of the Revolution on the Nuer was less evident. Their livestock economy was not affected by the reforms launched from Addis Ababa, nor was their highly diffused system of traditional authority disturbed. They settled dispersed in the remote districts of Jikow, Akobo, and Itang. Thus, the students sent to Zemecha from the center were unable reach. Geographical remoteness was not the only cause that prohibited torchbearers of the revolution from those areas, but also volatility to conflict. Besides poor infrastructures in the districts was a tiresome hurdle for the students of Zemecha [63]. Nevertheless, around five hundred students were sent to the Gambella subprovince as a member of the enlightenment project of Zemecha. Those students were assigned to Gambella, Itang, Abobo, Gog, and Jikow. The program for Jikow post was canceled because of the security problem. Members of the Zemecha who were appointed to Jikow distributed for other districts. Very backward social infrastructures such as road, bridge, and shelters brought difficulty to communicate with the people. Above all the language barrier made the challenges worse [64].

Despite those challenges, some reforms of the Revolution began to be implemented by representatives of the regime. The first enlightenment agenda that brought to the Nuer by the revolutionary government appointees was against feudal representatives of the monarchical period. The Derg delegitimized the authority and role given to local Balabats. They were considered servants of the reactionary feudal government. Representatives of workers party had been working eagerly to erode social acceptance of the respected Balabats. The Balabats were accused of conspiring against the establishment of farmers' associations. This was because of the honor and respect given to them from the community had been reduced. Their benefit from tax collection was stopped and role in the community was replaced by managers of farmers' associations.

The political motive of the Derg against the Balabats was clearly expressed in the memo from the minster of the ministry of the interior (Colonel Legesse W/Mariam) to Illubabour province on April 28, 1977.

... Yet, there were Kaworos in Anywak and Khors in Nuer who have got a leadership position by birth. The feudal 
government had used these leaders to collect taxes and exploit the people. Many of these leaders have given feudal titles such as Qegnazmach, Girazmach, Fitawurari, and Balambaras. Kaworos or Khors have magical and judicial authority. The people began to speak openly about the exploitation by the leaders [65].

The most important effect of the revolution and greatest contribution by the Derg to the Nuer was promotion in government posts. In 1987, the Derg promulgated a new constitution that created administrative and autonomous regions. Gambella was one of these autonomous administrative regions; a significant promotion from being a sub-province within Illubabour province, during the imperial period. Many Gaajak Nuer were put into high positions in local administration in Gambella and its sub-provinces. The Nuer vice-administrator was appointed as the administrator of the new Administrative Region of Gambella. Thuwat Pal was appointed as chief administrator and first secretary in the region. Thuwat was the son of Qegnazmach Pal Chay and had contributed a lot to stabilize the conflict in Gog and Jor district as an administrator [66].

\section{Conclusion}

There had been changes in the political arrangements and economic activities of Ethiopian Nuer. Increasing interaction with neighbors, socio-economic and political changes from the center, and some other factors brought readjustments. Some of those new circumstances had faced both resistance and support.

More profound changes observed in the political tradition of Nuer than their economic activities. Initially, they had practiced the egalitarian form of political tradition. They were divided into different clans and sub-clans. There were no imposed political authorities over those social divisions. Every Nuer had equal rights in the day to day life of the community. But there were respected individuals with specialized roles. The introduction of the Imperial administration to the Nuer changed preexisted political tradition. Individuals from the community were taken and adorned with new titles. It was an odd tradition for the egalitarian Nuer. There was an attempt to resist this political tradition. However, getting the strength of central administration incubated khors/Balabats among the Nuer. The role of those Balabats was to act as intermediaries between the people and government. Political changes in 1974 in the country also brought significant effects in the political history of Nuer. Khors/Balabats among the Nuer were regarded as reactionaries and ruminants of the old regime. The enlightening movement of the Derg abolished feudalism in the region. Thus, leaders with coercive political power had begun to emerge.

Economically, there were high dependency trends on pastoralism in the earlier periods. They had been showing greater affection for cattle. However, the emerging challenges dictated them to search for alternative economic activities. In this regard, farming had been given better emphasis to support their livelihood. Indeed, there existed discouraging natural hurdles on farming. Trade also showed relative growth.

\section{Acknowledgements}

First, my deepest gratitude goes to the able Almighty God. Then, I would like to express the greater contribution of individuals. Special thanks should be awarded for those who supported me professionally and morally in the course of compiling this study. I am also grateful for those interviewees who provided useful information.

\section{References}

[1] Hutchison Sharon Elaine. "Violence, legitimacy and prophecy: Nuer struggles with Uncertainty in South Sudan." Journal of American Anthropological society, 42, 3, 415-430, 2015, http://www./0.1111/amet.12138. Accessed on December 21, 2017.

[2] Gatwech tut riek. "Resource and political conflicts in Gambella Peoples National Regional State: The case of Itang Woreda," MA. Thesis, Addis Ababa University, 2016.

[3] Yonas Adaye. "Conflict complexity in Ethiopia: case study of Gambella regional state." Phd. Diss., University of Bradford, 2014.

[4] Hassen Nur Teha. "The Sudan Ethiopian boundry: a study in political geography." Phd. Diss., Durham University, 1971, http://etheses.dur.ac.uk/7922/. Accessed on January 10, 2018.

[5] Derege Feyissa. "Power and its discontent in Ethiopia's western periphery. Anwaas reaction to the consolidation of Ethiopian state in the Gambella region (1941-1991)." Addis Ababa Addis, Ababa University.

[6] Ojulu Ojot Miru. "Large scale land acquisition and minorities' indigenous people right. under ethnic federalism in Ethiopia: A regional case study of Gambella Regional State." Phd. Diss., University of Bradford, 2013.

[7] WRITENET, independent analysis. (2004). Ethiopia: The Gambella conflict - Structure and Prognosis, UK, http://www.refworld.org>pdfid, Accessed on January 24, 2018, p. 2.

[8] Mossa Hamid. "Conflict Dynamics in a Three-Level Game: the Conflict Formation in Gambella, Southwest Ethiopia." MA thesis, Addis Ababa University, 2014.

[9] DSA report. Expenditure Management and Control Program Assessment Report of Gambella Region. February, 2005.

[10] Koang Koang Kuch. "The role of multipurpose cooperatives in social and economic empowerment, in Gambella Town, Ethiopia." MA thesis, Mekelle University, 2013.

[11] Levin Donald N. Greater Ethiopia. Chicago and London, University of Chicago press, 1974.

[12] Pankhurst Richard. The Ethiopian border lands. Red sea pr. ltd, 1997.

[13] Evans E. Pritchard. The Nuer. Britain, At the Clarendon press, 1940. 
[14] Evans E. Pritchard. Nuer Religion. Britain, At the Clarendon press, 1956.

[15] Stringham Noel. "Marking Nuer histories: Gender, Gernotocracy, and the politics of Inclusion in the upper Nile from 1400- 193." Phd. Diss., University of Virginia, 2016.

[16] Falge Christian. "The Nuer as Refugees: a study of social adaptation." MA thesis, Addis Ababa University, 1997.

[17] Dereje Feyissa. "The Nuer between Ethiopia and the Sudan". Proceedings of the 16th International Conference of Ethiopian Studies, ed. By Svein Ege, Harald Aspen, Birhanu Teferra and Shiferaw Bekele, Trondheim 2009 and "The Pur, the real, and the chosen: the encounter between Anywa, the Nuer and Highlanders in Gambella," Flix Girke (ed). Ethiopian images of self and other, Germany, universitatsveslag Have Wittenberg, 2014.

[18] Temesgen Gebeyehu. "Identity, centralization and resistance in Ethiopia: the case of Nuer And Anywaa." African journal of political science and international relations, 2014. http://www.academic journals.org /AJPSIR. Accessed on September 15, 2017.

[19] Temesgen Gebeyehu. "Ethnic conflict, interaction and cohabitation in Africa: the case of Nuer and Anuwak." Eastern Africa Social Science Research Review, Volume 29, Number 2, June 2013, pp. 97-112.

[20] Gatluak Boum. interviewed by the author, Gambella town, December 14, 2017. He was born and grown in Nuer zone. He is one of the grand sons of Qegnazmach Pal Chay. He has MA degree.

[21] Zewude Dubale. Ilubabor. Addis Ababa, 1976.

[22] Medhane Tadesse. "Gambella: the impact of local conflict on regional conflict." Institute of Security studies, Pretoria.

[23] Endalkachew Girma. "Assessing impact of south Sudanese refuges on the host community of Itang woreda: a case study of Tierkidi refugees camp in Gambella regional state." MA thesis, Addis Ababa University, 2016.

[24] Regassa Bayissa. "The Derg-SPLM/A Cooperation: An Aspect of Ethio-Sudan Proxy Wars". EJOSSAH Vol. V, No. 2 pp. 19- 44. December 2007.

[25] Dereje Feyissa. "The cultural construction of state borders: the view from Gambella", Journal of Eastern African Studies, 4: 2 , (2010), DOI: 10.1080/17531055.2010.487341.

[26] Changing Ethnic Relations. A Preliminary Investigation of Gambella, Southwest Ethiopia Alexander Meckelburg, AsienAfrika-Institut der Universität Hamburg.

[27] Medhane Tadesse. Gambella: the impact of local conflict on regional conflict and Dereje Feyissa, "A National Perspective on the Conflict in Gambella."

[28] Bol Bouny, interviewed by the author, Gambella town, December 10, 2017. He was born and lived in Nuer Zone. He is lecturer at Gambella teachers college and has MA degree in social work. He has also better understanding about Ethiopian Nuer. He wrote Nuer English dictionary.

[29] The ancient History of Nuer and their advantage from EPRDF constitution. Presented to the tenth Ethiopian nations nationalities and peoples day. Gambella, 2015.

[30] Bol Bouny, and Sharon Elaine Hutchison, "Violence, legitimacy and prophecy: Nuer struggles with Uncertainty in South Sudan.”

[31] Bahiru Zewude. "Relation Between Ethiopia and the Sudan on the western Ethiopian frontier, 1898 - 1935." Phd. Diss., University of London, May 1976.

[32] Jacob Babouth interviewed by the author on December 27, 2017 in Itang Town. He has good memory of oral Traditions.

[33] Tasew Gashaw. "Cross-Border Intergroup Conflicts in the Horn of Africa: A Case Study of Ethiopia-South Sudan Borderland People". Southern Voices Network for Peace $\begin{array}{lll}\text { building Scholar, } & \text { November }\end{array}$ https://www.wilsoncenter.org/article/the-southern-voicesnetwork-for-peacebuilding. P. 39.

[34] Ethiopian National Archives and Library Agency. A memo written from ministry of interior to Illubabour province regarding about the people. April, 1977.

[35] Ethiopian National Archives and Library Agency. A memo to the V/prime minister of Ethiopia in June 1990 and Ministry of interior to Illubabour province, regarding shortage of rain, on August 16, 1990.

[36] Kawich Puok. "The subject matter of Nuer proverbs: Lare community of Gambella." MA thesis, Addis Ababa University, 2012.

[37] Siwan Anderson. "The economics of dowery and brideprice." Journal of economic perspectives, 2007. Volume (4) p. 151174.

[38] Ethiopian National Archives and Library Agency. A memo written from the delegate office of ministry of agriculture at Metu to Gambella regarding the climate changes in Gambella awraja. July, 1982.

[39] Bol Kiet, interviewed by the Author, Gambella town, December 19, 2017. He was a teacher during the Derg regime. He has good memory about the events among Nuer. He is among Yehager shimagele now.

[40] Ethiopian National Archives and Library Agency. Gambella sub province, 1982, report on drought in the sub province (Gambella, August 29, 1982).

[41] Cascao Ana Elisa. Resource based conflict in South Sudan and Gambella (Ethiopia): when Water land and oil mix with. Center of African studies. University institute of Lisbon, 2013. 143-165.

[42] Gatluak Ruon Jal. "The Roots Cause of Cross Border Conflict in Gambella Regional State between Jikany-Nuer and LouNuer." Public Policy and Administration Research. Vol. 4, No. 8, 2014.

[43] Phillip T. Manyok. "Cattle rustling and its effect among the three communities (Denka, Murle, And Nuer) in Jonglei state South Sudan.” Phd. Diss., Nova Southestern University, 2017.

[44] Tut Pal interviewed by the author, Gambella town, on February 13, 2018. He is the son of Qegnazmach Pal Chay. At the time of interview he was a judge at Gambella national regional state.

[45] Caplan Caplan Aadrew Stephen. "British Policy towards Ethiopia, 1909-1919.” Phd. Diss., University of London, 1971

[46] Collins Robert. O. Land Beyond the Rivers: The Southern Sudan, 1898-1918, New Haven: Yale University Press, 1971. 
[47] Beyene Hamere Tibeb, interviewed by the author, Gambella town, December 10, 2017. He lived in the area for more than 20 year and has been serving as a teacher. He has MA degree in history and currently working in Gambella teachers college.

[48] Zewude Dubale. Ethiopian National Archives and Library Agency. 1963/4, Annual report. (Gambella, Gambella subprovince, in 1965).

[49] Mawut Lazarus Leek. "The southern Sudan under British rule 1898-1924: the constraints Reassessed.” Phd. Diss., Durham University, 1995, http://etheses.dur.ac.uk/971/. Accessed on May 5, 2018.

[50] Dereje Feyissa. "A National Perspective on the Conflict in Gambella." In: Proceedings of the 16th International Conference of Ethiopian Studies. Svein Ege, Harald Aspen, Birhanu Teferra and Shiferaw Bekele (Eds). Trondheim, 2009.

[51] Bol kiet. Interviewed by the author on December 19, 2017 at Gambella Town. He was a teacher during the Derg regime. He has good memory about the events among Nuer. $\mathrm{He}$ is national elder.

[52] Ethiopian National Archives and Library Agency. The memo Ekube Mikael Alem Birhan to Gambella Sub Province, concerning the conflict between Balabats, may8, 1974.

[53] Ethiopian National Archives and Library Agency. Blata Tsehay Desta to Ministry of Interior, memorandum regarding the way of life of Gambella people, August 31, 1957, Gambella sub-province administration.

[54] Diedrich westernman. Some notes and short vocabulary of the Anywak. Berlin, 1912.

[55] Ethiopian National Archives and Library Agency. Lemma G/Mariam to Bitwoded zewude G/Hiwot, memo concerning the existing situations of Gambella sub-province, March 3, 1970, Ministry of Interior from Gambella sub-province.

[56] An application letter from local Balabats to Jikow district governor in August 1974.

[57] Thuwat Pal, telephone conversation, February 13, 2018. Tut was born and lived in Jikow. One of the sons of Qegnazmach
Pal Chay. He was also chairman of EWP, and secretary of Gambella administrative region during the Derg.

[58] Ethiopian National Archives and Library Agency. Gambella sub-province Governor, 1958 annual report (Tsehay Desta, Gambella, June 24, 1958).

[59] Ethiopian National Archives and Library Agency. Abera G/Egzibher to ministry of interior, A memo regarding pastoralists, Illubabour province, on October 18, 1983.

[60] Ethiopian National Archives and Library Agency. Fitawurari W/Semayat Tesema to L/General Abiy Abebe, memo regarding flooding of Pibore River, Ministry of Interior from Illubabour province, on January 2, 1962.

[61] Belete Belachew. Ethiopia's Role in South Sudan's March to Independence: 1955 -1991. African Studies Quarterly | Volume 14, Issues $1 \quad \& \quad 2 \quad \mid$ November 2013. http://www.africa.ufl.edu/asq/v14/v14i1-2a3.pdf. Pp 36-54.

[62] Ethiopian National Archives and Library Agency. Fitawurari, Zewude Otore to ministry of interior. Memo concerning infrastructure in Gambella. On December 6, 1974 Illubabour province $\mathrm{v} / \mathrm{c}$ governor.

[63] Ethiopian National Archives and Library Agency. M/General Dires Dubale to the minister of Ministry of Defense. A memorandum regarding security. On October 23, 1968 Ministry of Interior Department of Public Security. Addis Ababa.

[64] Derege Feyissa. "The Pur, the real, and the chosen: the encounter between Anywa, the Nuer and Highlanders in Gambella," Flix Girke (ed). Ethiopian images of self and other, Germany, universitatsveslag Have -Wittenberg, 2014.

[65] Ethiopian National Archives and Library Agency. Legesse W/Mariam to Illubabour province. General information on the people of Gambella. Minister of the ministry of interior, April $28,1977$.

[66] Gatluak Tut interviewed by the author in lare, on December 18,2018 . He has blood relation with Girazmach Tongik Tenjah. 